\title{
*Study of inhibitory activity for rhamnolipid produced by Pseudomonas aeruginosa against some types of pathogenic bacteria in vivo
}

\author{
Received : 7/12/2017 \\ Maha Hani Tawfeeq ${ }^{1}$, Buthaynah Shaheed Yesser ${ }^{2}$ \\ ${ }^{1}$ College of Medicine, University of Al-Qadisiyah, Diwaniyah, Iraq. \\ ${ }^{2}$ College of Nursing, University of Al-Qadisiyah, Diwaniyah, Iraq. \\ E-mail: maha_emm@yahoo.com , buth.buth74@gmail.com
}

Accepted : 18/1/2018

\begin{abstract}
:
Fifty-one isolates of Pseudomonas spp. were isolated from various sources (pathological clinical cases) and non-pathological (contaminated and uncontaminated soil). Twenty-three isolates were identified as $P$. aeruginosa. Then two $P$. aeruginosa isolates $(P$. aeruginosa PP10 from the clinical case isolates and $P$. aeruginosa PS16 from the soil isolates) were selected for production and extract the Rhamnolipid. The Rhamnolipid was diagnosed by Thin-layer Chromatography (TLC) and show that the two bacterial isolates produced 3 types of rhamnolipids (mono-, di-rhamnolipid and rhamnolipid A). As well as they diagnosed by High-performance Liquid Chromatography (HPLC). This study also determines the values of minimum inhibitory concentration (MIC) and minimum bactericidal concentration (MBC) for biosurfactants and the results was varied depending on the different type of biosurfactants and type of bacteria with lowest values of MIC and MBC for biosurfactants produced by $P$. aeruginosa. The inhibitory effects of these biosurfactant that under study against types of bacterial pathogens ( $S$. aureus and $P$. aeruginosa) with in vivo after making skin injury on back of laboratory mice and contaminated with bacterial pathogens. The clinical symptoms of infection to injured skin emerged after 48 hours. Then mice grouped to treat them with biosurfactants at concentration of 30 milligrams / milliliter produced in this study by two bacterial isolates $P$. aeruginosa PP10 and $P$. aeruginosa PS16, resulting in a reduction in the time required for recovery. The results obtained showed the difference in the time required for recovery (depending on the nature of the injury and the type of the microorganism causing the infection), which was cured within 5 days when the concentration was $30 \mathrm{mg} / \mathrm{ml}$ of biosurfactant produced by P. aeruginosa P.16, followed by a group of mice that recovered after 6 days when the concentration of $30 \mathrm{mg} / \mathrm{ml}$ was used by $P$. aeruginosa PP10 compared to the control mice which recovered after 12 days for mice groups infected with $S$. aureus. As for $P$. aeruginosa infected groups, they were cured after 10 days later when $30 \mathrm{mg} / \mathrm{ml}$ concentration was used for biosurfactant produced by $P$. aeruginosa PS16, followed by a group of mice that recovered after 12 days when the $30 \mathrm{mg} / \mathrm{ml}$ of biosurfactant produced by $P$. aeruginosa PP10. In compared to control group mice that was cured after 17 days. From the results of research, we conclude that rhamnolipid was showed effectiveness against different types of bacteria and reduced time of recovery from infections in vivo.
\end{abstract}

Key words: P. aeruginosa, rhamnolipids, The inhibitory efficacy of bacteria 


\section{Introduction:}

Biosurfactants are amphiphilic compounds produced on living surfaces, mostly microbial cell surfaces, or excreted extracellularly and contain hydrophobic and hydrophilic moieties that reduce surface tension and interfacial tension between individual molecules at the surface and interface, respectively [1]. They find applications in an extremely wide variety of industrial processes involving emulsification, foaming, detergency, wetting, dispersing or solubilization [2]. They are a group of structurally diverse molecules with surface activity and variety chemical structure such Glycolipid, lipopeptides, Lipoprotein, Fatty acids, Neutral lipids, Phospholipids and Polymeric particulate structure [3],[4].

Glycolipid is one of the most important biosurfactants, which has been studied largely because of its many uses and the possibility of obtaining high productivity by using many sources of saccharides and hydrocarbons as source for the production of these compounds compared to other types of biosurfactants. Biosurfactants can be produced from cheap sources or waste products, as opposed to chemical surfactants derived from oil as raw material [5]. There are many surfactant are produced nowadays such as Rhamnolipids from P. aeruginosa, surfactin from Bacillus subtilis, emulsan from Acinetobacter calcoaceticus and mannosyl erythritol lipids (MELs) from Pseudozyma yeasts [2],[6],[7],[8],[9]. Several sources reported that biosurfactants had inhibitory activity against a number of microbes [10]. Biosurfactant rhamnolipids has been shown to inhibit the tendency of many microorganisms such as Clostridium perfringens, Enterobacter aerogenes, Escherichia coli, Salmonella typhimurium, Phytophthora infestans, Phytophthora capsici,

Botrytis cinerea, Fusarium graminearum and Mucor spp.[11],[12],[13].

The current study aimed to measure the inhibitory activity of the rhamnolipis produced by $P$. aeruginosa bacteria isolated from clinical pathogens and from soil using soybean oil as a source of carbon against bacterial pathogens in vivo.

\section{Materials and methods:}

Twenty-six pathological samples were obtained from the specialized burns hospital and the educational laboratories in Baghdad governorate and 25 non-pathological samples from soil from different regions of Baghdad governorate from February 2015 until June 2015 isolates of $P$. aeruginosa were identified using [14],[15] methods. Also API20NE system had been used to further confirm for this type of bacteria because it includes a number of important biochemical tests that help confirm the diagnosis.

\section{Bacteria used:}

Two isolates were diagnosed and tested in the Microbiology Laboratory / Department of Biology / College of Science for Girls / University of Baghdad, including Staphylococcus aureus and Pseudomonas aeruginosa.

\section{Extraction of biosurfactant:}

The compound was extracted according to the method described by [16] to extract fatty compounds from the biomolecules. The bacterial culture of the $P$. aeruginosa bacteria collected from pathological and nonpathological sources was diagnosed according to the classification keys adopted by [14], were centrifuged by at 8000 cycles / minute for 30 minutes at $4{ }^{\circ} \mathrm{C}$. The compound was extracted with solvent chloroform methanol by 1: 2 volume / volume, so that the chloroformmethanol ratio (filtrate free of bacterial cells) was (8:2:3), and then the solvent was evaporated and the surfactant was obtained as powder.

\section{Separation and purification of biosurfactants} by using gel filtration chromatography:

The separation and purification of biosurfactant was carried out by using $(20 \mathrm{~g})$ of silica gel 60 (BDH British company) for each gram of biosurfactant extract. After soaking the silica gel 60 with chloroform for an hour and 
preparing a column of silica gel 60 with dimensions $(40 \times 2) \mathrm{cm}$ inside glass column 60 $\mathrm{cm}$ in length and $2 \mathrm{~cm}$ diameter, then added $2 \mathrm{~g}$ biosurfactant extract that dissolved with $4 \mathrm{ml}$ chloroform, and rinsed with to remove the yellow color and collect the liquid from the column in $5 \mathrm{~mL}$ tubes. Then rinsed with chloroform methanol with ratio (5: 2) respectively and collecting the exit liquid from column in $5 \mathrm{ml}$ tubes. The solvent evaporated to won biosurfactant as powder [17].

\section{Detection of Rhamnolipid by Thin layer} chromatography (TLC):

Thin layer chromatography was applied by using silica gel plats $(20 \times 20 \mathrm{~cm})$ and $0.25 \mathrm{~mm}$ thickness (Merek Company) to diagnose rhamnolipids. The solvent system was used as chloroform: methanol: water $(2: 15: 65)$ (size: Size: size) depending on the method [18] to determine the number and locations of spots and determine the components of the compound.

Diagnosis of biosurfactants by High performance liquid chromatography

\section{(HPLC):}

In this experiment was used HPLC. An the standard rhamnolipid was from Sigma Chemical company and column $\mathrm{C} 18$ with dimensions (4.6 x 5) $\mathrm{mm}$ from Shimadzu company - Japan with RA detection at a wavelength of $262 \mathrm{~nm}$ and mobile phase consist of $0.2 \%$ of (A) formic acid in ions-free water and (B) methyl cyanide for HPLC. The flow velocity for mobile phase was $1.4 \mathrm{ml} / \mathrm{min}$ at $35^{\circ} \mathrm{C}$.

\section{Minimum inhibitory concentration MIC and} Minimum bactericidal concentration:

Antimicrobial activity was determined on the basis of minimal inhibition concentration (MIC) values, defined as the lowest concentration of antimicrobial agent needed to inhibit the development of visible growth after incubation for the required time [19]. A standard two-fold serial rhamnolipid dilution technique was applied to measure antimicrobial activity [20].
MIC was estimated for biosurfactants that showed antimicrobial effects, which $10 \mathrm{mg} / \mathrm{ml}$ concentration of biosurfactant used and serial dilution prepared at $(0.065,0.125,0.25,0.5,1$, $2,4,8,16,32,64,128,256$ and 512) under study, by preparation of suspension from young isolates by carrying (3-5) young pure colonies to tubes contain Muller Hinton broth that contain $\mathrm{Ca}^{2+}, \mathrm{Mg}^{2+}$ and tubes incubated at $37^{\circ}$ $\mathrm{C}$ for 12 hour than absorption for suspension was measured at wave length 650 nanometer.

Standard microplate was used with 96 round concave holes. In first hole was added bacterial suspension without biosurfactant +ve control and second hole Muller Hinton broth contain $\mathrm{Ca}^{2+}, \mathrm{Mg}^{2+}$ as -ve control, after that 100 microliter rom each concentration of biosurfactants $(0.065$ - 512) microgram/ ml then 5 microliter from bacterial suspension was added to each hole. The plate incubated at temperature $37^{\circ} \mathrm{C}$ for $18 \mathrm{hr}$. [20].

\section{Test of inhibitory effects of biosurfactant in} vivo:

36 Swiss white males' mice (albino Mus musculus) with 8-10 weeks old and (20 - 24 gram) weighting. They were placed in animal's house of Al-Nahrain University with standard environment situations temperature $(25-28$ $\mathrm{C}^{\circ}$ ). Mice kept in animal house for acclimation to the laboratory condition for one week before using them. They were divided into several groups with 3 mice in each group. Mice hairs were shaved from back area and wound has been done with sterile scalpel.

A - The first group control group, which divided into several subgroups are: -

1 - Healthy mice

2 - Wounded mice with non-bacterial suspension contamination.

3 - Wounded mice with bacterial suspension contamination.

4 - A group of wounded mice with nonbacterial suspension contamination and given treatment.

B - The second group 
Which it were included wounded mice with $P$. aeruginosa bacterial suspension contaminated at age $18 \mathrm{hr}$. with concentration 1 x $10^{8}$ bacterial cell $/ \mathrm{ml}$ after comparing with turbidity McFarland standard solution tubes.

C- The third group

AS in the second group but used B. cereus suspension for made wound infection.

Treatment of laboratory animals:

All groups were treated by dropping on the wound area with biosurfactants at concentration of $30 \mathrm{mg} / \mathrm{ml}$, with taking into account the length of time required for disease symptoms appear. It was 48 hours for the bacteria as well as the control group.

\section{Results and discussion}

When microscopically examination for bacteria samples was performed, the bacteria appeared as Gram negative single rod-shaped bacterium or short chains this is agree with [14], [15] and macroscopically examination for grown colonies on Mc Conky agar as pale colonies but did not ferment lactose. A single colony was chose from each isolate and cultured on blood agar in which riche activated media to determine bacterial ability to hemolysis and its type. It was complete hemolysis ( $\beta$-hemolysis) and showed a translucent halo appeared around the colony and observation bacterial growth at $42^{\circ} \mathrm{C}$ as bacteria cultured on nutrient agar and incubated at a temperature of $42^{\circ} \mathrm{C}$. The results showed the ability of all isolates to grow at $42{ }^{\circ} \mathrm{C}$, and it is an important diagnostic feature of $P$. aeruginosa from the other Pseudomonas species. This is agreeing with [21]. Then isolates cultured on tow selective media (Citrimide agar and King A) for P. aeruginosa and the growing colonies on these Medias characterized by regular round shop and produced fluorescein and pyocyanin. Also the bacterial isolates were identified based on the results of the chemical tests as shown in Table (1).

Table (1) Results of the chemical tests used in the diagnosis of $P$. aeruginosa bacteria

\begin{tabular}{|c|c|c|c|c|c|c|c|c|c|c|}
\hline$\stackrel{\mathscr{心}}{\mathscr{0}}$ & 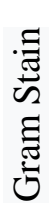 & 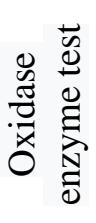 & 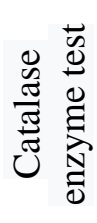 & 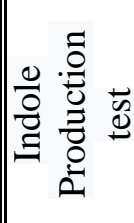 & 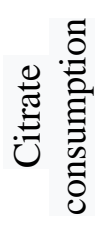 & 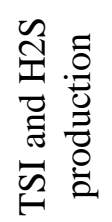 & 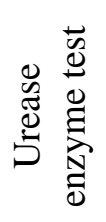 & 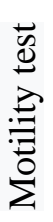 & 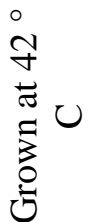 & 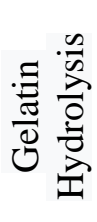 \\
\hline results & - & + & + & - & + & $\mathrm{K} / \mathrm{K}--$ & $\mathbf{V}$ & + & + & + \\
\hline
\end{tabular}

$(+)=$ positive result

$(-)=$ negative result

$($ TSI $)=$ Triple sugar iron

(K) = Alkaline

API 20NE diagnostic system was used which include important biochemical tests for further confirmation diagnosis of this bacteria as showed in table (2). 
Table (2) Results of diagnosis of $P$.aeruginosa isolates under study for Api20NE test

\begin{tabular}{|c|c|c|}
\hline Test type & P.aeruginosa PS16 & P.aeruginosa PP10 \\
\hline $\mathrm{No}_{3}$ & + & + \\
\hline TRP & - & - \\
\hline GLU & - & - \\
\hline $\mathrm{ADH}$ & - & - \\
\hline URE & - & - \\
\hline ESC & - & - \\
\hline GEL & + & + \\
\hline PNG & - & - \\
\hline GLU & + & + \\
\hline ARA & - & - \\
\hline MNE & - & - \\
\hline MAN & + & + \\
\hline NAG & + & + \\
\hline MAL & - & - \\
\hline $\begin{array}{l}\text { GNT } \\
\end{array}$ & + & + \\
\hline CAP & + & + \\
\hline $\mathrm{ADI}$ & + & + \\
\hline MLT & + & + \\
\hline CIT & + & + \\
\hline PAC & - & - \\
\hline OX & + & + \\
\hline
\end{tabular}

The biosurfactants was extracted that produced by Pseudomonas aeruginosa PS16 and Pseudomonas aeruginosa PP10 isolates which collected during this study after growing them in soybean and mineral salts using FLOCH method by adding solvent chloroform - methanol (2: 1) (volume: volume), solvents mixture method to give large quantities [22]. 15.45 gram and 18.25 gram of biosurfactants were obtained in 1litter from tow selected bacterial isolates PP10 and PS16. Biosurfactants produced by selected isolates have brown to yellowish color as in figure (1A) and viscous at room temperature, these results agreed with results obtained by [22], [23]. After that the separated and purified biosurfactant were carried out and the product of separated and purified biosurfactants from selected isolates have honey color as in figure (1-B).The produced biosurfactants were obtained from this study diagnosed by using thin layer chromatography on silica gel plates and the results showed that produced compounds had lipid part and saccharide part. 
A positive result was obtained with $\alpha$-Naphthol reagent that used in detection of liposaccharide result purple color. Also, brown color spots were appeared with phenol-sulfuric acid reagent which specific for detection carbohydrates in lipids. Spots were noted in three different locations indicating that the emulsion is composed of three complexes, one of which is different from the other by molecular weight. The results showed that the relative force value (Rf) for the first compound with the largest molecular weight was equal to $(0.3)$ and the second with the lesser molecular weight was equal to (0.6) and the third with lowest molecular weight was (0.82) for PS16 isolate.

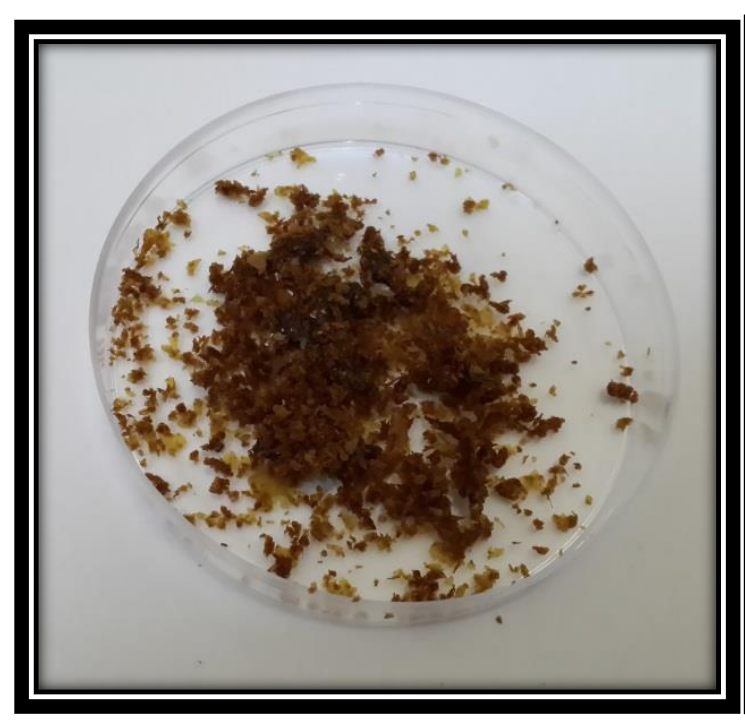

( A )

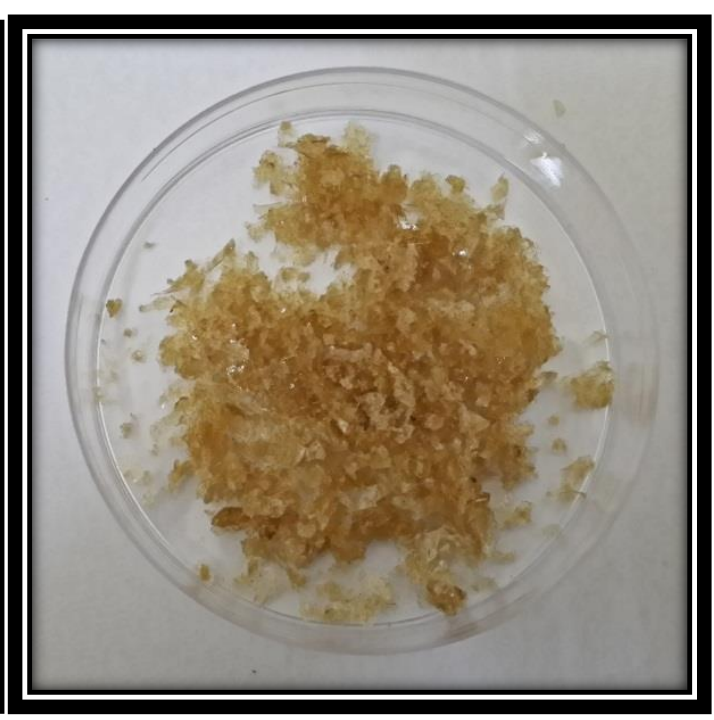

( B )

\section{Figure 1: Biosurfactants produced by selected isolates from $P$. aeruginosa bacteria}

\section{(A) Row biosurfactant}

As for PP10 isolate, the relative force values were equal to $0.28,0.59$ and 0.83 respectively. These results approach to (Rf) obtained from other studies using the same solvent system (chloroform: methanol: water 65:15:2 volume / volume / volume) [18]. From reactions to detect groups of the three complexes, the results showed that they had a fatty nature and contained a saccharide group. When using the high performance liquid chromatography technique to diagnose the biosurfactants obtained in this study, HPLC was injected with $0.02 \mathrm{ml}$ of pure substance and used in

\section{(B) purified biosurfactant}

elicitation of the standard RA curve as shown in figurer (2). The results of the analysis showed that the extracts of both biosurfactants contained three complexes: mono-rhamnolipid, dirhamnolipid, and rhamnolipid a, with different concentrations. The concentrations of the extract from $P$. aeruginosa PS16 were mono-rhamnolipid $42.93 \mu \mathrm{g} \mathrm{/} \mathrm{mL}$ and dirhamnolipid $20.42 \mu \mathrm{g} / \mathrm{mL}$ and rhamnolipid a $44.36 \mu \mathrm{g} / \mathrm{ml}$, and for the product extract from P. aeruginosa $\mathrm{PP} 10$, the concentrations (29.1920.69 - 27.64) $\mu \mathrm{g} / \mathrm{mL}$ respectively, as shown in Figures (3) and (4). 


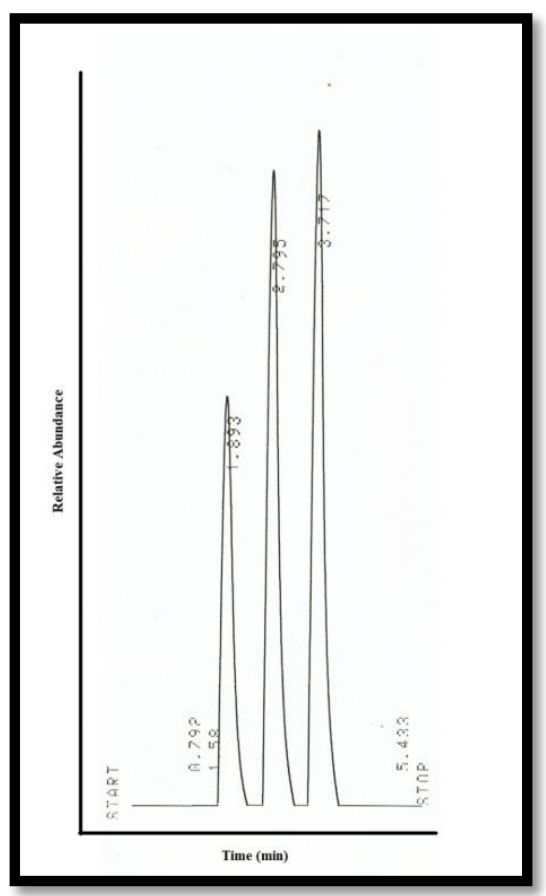

Figure (2) the standard curve of the standard Rhamnolipid compound

The peak $(1)=$ represents complex R1

The peak $(2)=$ represents complex R2

The peak (3) = represents complex R3
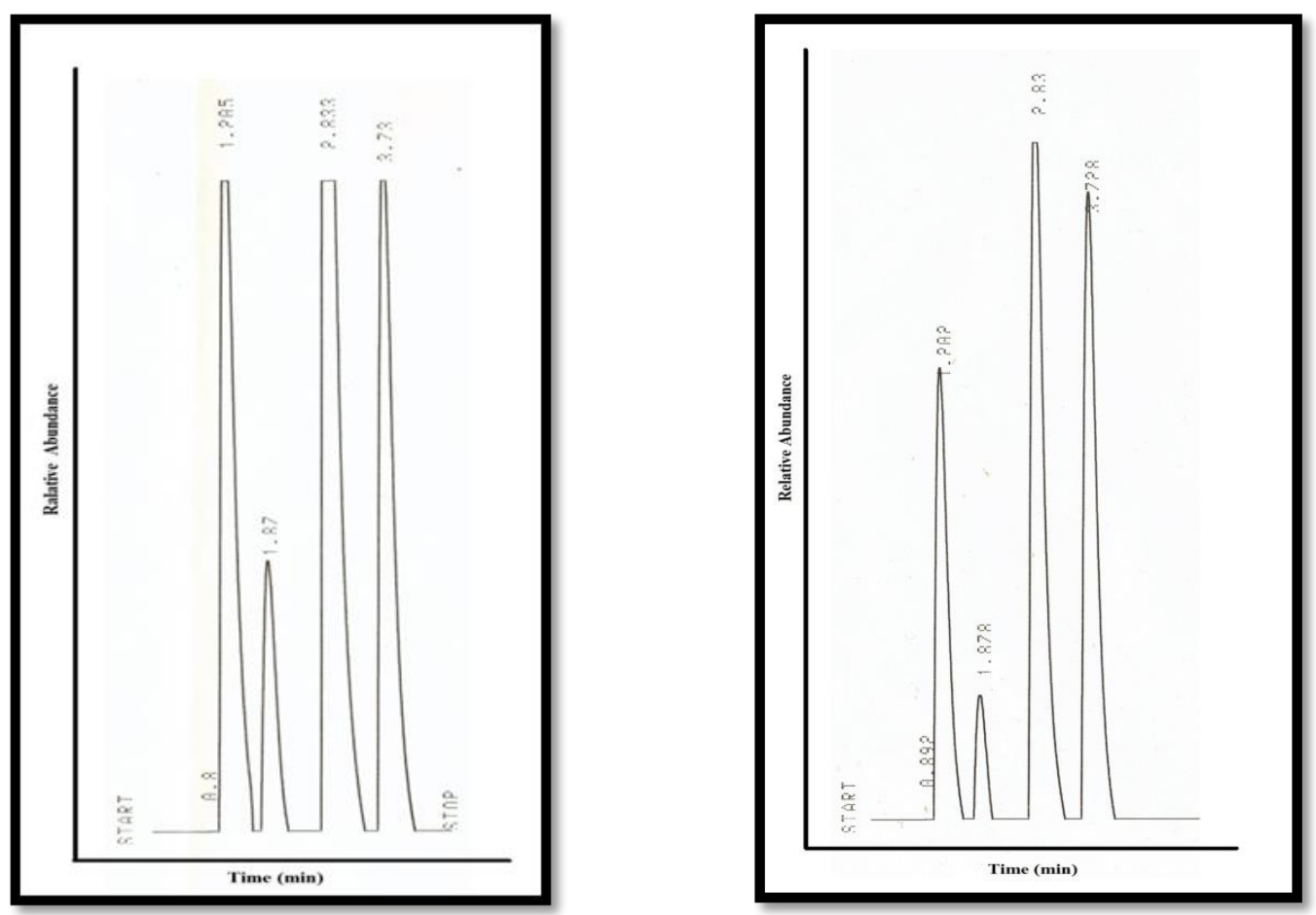
Figure (3) HPLC analysis of the

Rhamnolipid produce from $P$. aeruginosa PS16 bacteria.

Also the minimal inhibitory concentration (MIC) had been determined which it is the lowest concentration of antibacterial agent that inhibit growth of bacterial colonies as much as possible and minimal bactericidal concentration (MBC), which is measure the least concentration of antimicrobial agent that reduce the number of colonies by $99.9 \%$ from original bacterial growth [24], this done through mixing biosurfactants in different concentrations with broth media cultured with diluted bacterial suspension. The results showed an increase in
Figure (4) HPLC analysis of the

Rhamnolipid produce from $P$. aeruginosa PS10 bacteria.

activity of biosurfactant by increasing its concentration. MIC and MBC values vary depending on biosurfactant concentration and bacterial strain produced it and effected by it as shown in table (3) in which recorded the lowest MIC value for biosurfactant produced by $P$. aeruginosa PS16 was $16 \mu \mathrm{g} / \mathrm{ml}$ for $S$. aureus bacteria growth while the lowest value for biosurfactant produced by P. aeruginosa PP10 was $128 \mu \mathrm{g} / \mathrm{ml}$ also for $S$. aureus bacteria growth.

Table (3): The minimum inhibitory concentration and the minimal bactericidal concentration of the biosurfactants produced from $P$. aeruginosa PS16 and $P$. aeruginosa PP10 against some pathogenic bacterial isolates under study.

\begin{tabular}{|c|c|c|c|c|c|}
\hline \multirow{2}{*}{ Bacterial isolates } & \multicolumn{2}{|c|}{$\begin{array}{c}\text { Biosurfactant concentration } \\
\text { produced from P. aeruginosa } \\
\text { PS16 } \mu \mathrm{g} / \mathrm{ml}\end{array}$} & $\begin{array}{c}\text { Biosurfactant concentration } \\
\text { produced from P. aeruginosa } \\
\text { PP10 } \mu \mathrm{g} / \mathrm{ml}\end{array}$ \\
\cline { 3 - 6 } & & MIC & MBC & MIC & MBC \\
\hline 1 & S. aureus & 16 & 32 & 128 & 256 \\
\hline 2 & P. aeruginosa & 128 & 256 & 256 & 256 \\
\hline
\end{tabular}

Skin lesions were developed experimentally in laboratory mice with $S$. aureus bacterial suspension. After 48 hours, clinical signs were observed in the affected area, which was initially characterized by skin inflammation, swelling and redness in the affected area with abscesses and purulence discharge in the superficial layer of the skin progressed to purple patch (Fig. 5A) as mentioned in previous studies [25],[26],[27].
When treatment of infected mice with biosurfactant produced from bacterial isolates under study, they were cured after 5 days when the concentration of $30 \mathrm{mg} / \mathrm{ml}$ of the biosurfactant produced by P. aeruginosa PS16 was used for the first group (Fig. 5C) followed by mice of second group were recovered after 6 days when used same biosurfactant concentration produced by P. aeruginosa PS10 (Fig. 5D) compared with control group which recovered after 12 days (table 4 ). 
Table (4) the recovery period by day for mice groups infected by $S$. aureus bacteria and the treatment by biosurfactant produced by $P$. aeruginosa PS16 and $P$. aeruginosa PP10 isolates at a concentration of $30 \mathrm{mg} / \mathrm{ml}$.

\begin{tabular}{|c|c|c|c|c|}
\hline & & \multicolumn{3}{|c|}{ Recovery days } \\
\cline { 3 - 5 } Mice group & $\begin{array}{c}\text { Number of } \\
\text { mice in each } \\
\text { group }\end{array}$ & $\begin{array}{c}\text { Biosurfactant } \\
\text { produced from } \\
\text { P. aeruginosa } \\
\text { PS16 }\end{array}$ & $\begin{array}{c}\text { Biosurfactant } \\
\text { produced from } \\
\text { P. aeruginosa } \\
\text { PP10 }\end{array}$ & $\begin{array}{c}\text { Without } \\
\text { biosurfactant }\end{array}$ \\
\hline $\begin{array}{c}\text { Mice with non- } \\
\text { contaminated } \\
\text { wounds by bacterial } \\
\text { suspension }\end{array}$ & 3 & 5 & 5 & 7 \\
\hline $\begin{array}{c}\text { Mice with } \\
\text { contaminated } \\
\text { wounds by bacterial } \\
\text { suspension }\end{array}$ & 3 & 5 & 6 & 12 \\
\hline
\end{tabular}

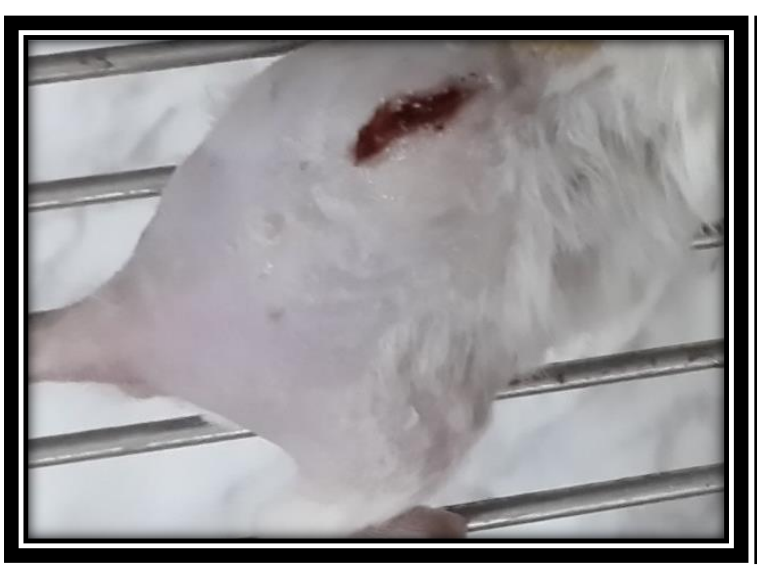

A) Sign of bacterial infection with S. aureus in experiment animals.

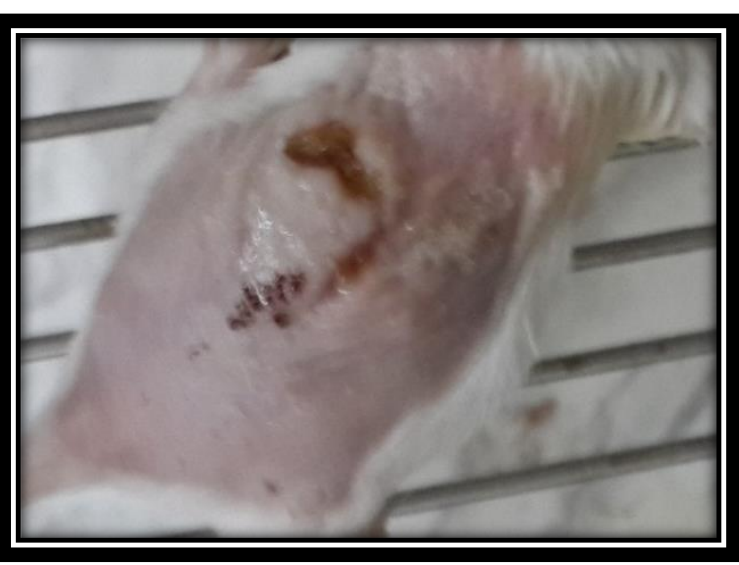

B) Progression of infection in control mice group without treatment after 6 days.
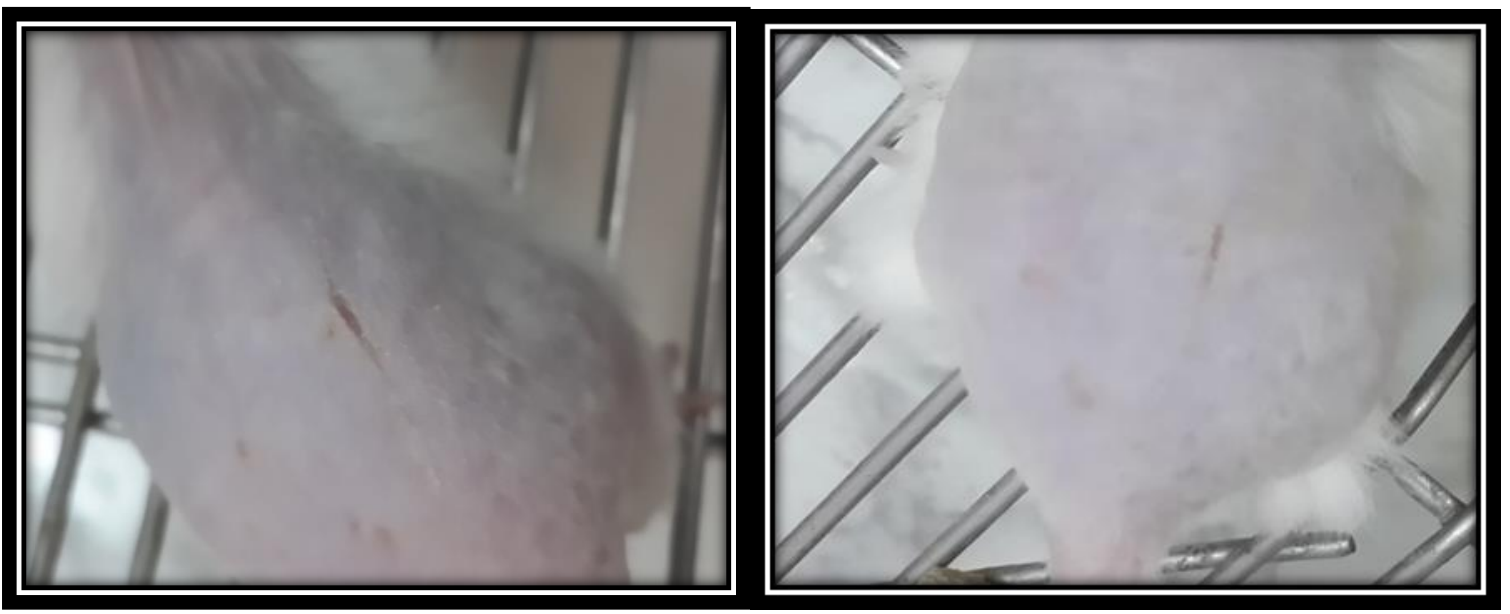
C) Complete recovery after 5 days for infected animals treated with biosurfactant produced by $P$.aeruginosa PS16 at concentration $30 \mathrm{mg} / \mathrm{ml}$
D) Complete recovery after 6 days for infected animals treated with biosurfactant produced by $P$.aeruginosa $\mathrm{PP} 1$ ) at concentration $30 \mathrm{mg} / \mathrm{ml}$

Figure (5) mice infected by $S$. aureus bacteria and treated with biosurfactant produced by $P$. aeruginosa PS16 and $P$. aeruginosa PP10 isolates.

And skin lesions were developed experimentally in laboratory mice with $P$ .aeruginosa bacterial suspension. The clinical signs for infected skin appeared after 48 hours characterized by redness and necrosis in affected tissue with green bluish purulent discharge, and progressed to ulcers then to scar or pimple with gray or black center and developed to blue green region because of pigment excreted by this bacteria and coloration the affected tissue by it as in (Fig. 6A), this result come with study in [26]. Most references reported that these pathogenic bacteria are difficult to treat, and continue until the infection becomes chronic, which is related to the many virulence factors that release them, which lead to necrosis of the affected area and delayed healing [26], [ 28].

The results for treatment of skin infection by biosurfactant produce from tow isolates under study showed that they were cured after 10 days when biosurfactant was used at concentration $30 \mathrm{mg} / \mathrm{ml}$ that produced by $P$. aeruginosa PS16 (Fig. 6C), followed by mice group were cured after 12 days when biosurfactant was used at concentration $30 \mathrm{mg} / \mathrm{ml}$ that produced by $P$. aeruginosa PP10 (Fig. 6D), when they compared with the control group, which recovered after 17 days (Table 5)

Table (5) the recovery period by day for mice groups infected by $P$. aeruginosa bacteria and the treatment by biosurfactant produced by $P$. aeruginosa PS16 and $P$. aeruginosa PP10 isolates at a concentration of $30 \mathrm{mg} / \mathrm{ml}$.

\begin{tabular}{|c|c|c|c|c|}
\hline & & \multicolumn{3}{|c|}{ Recovery days } \\
\cline { 3 - 5 } Mice group & $\begin{array}{c}\text { Number of } \\
\text { mice in each } \\
\text { group }\end{array}$ & $\begin{array}{c}\text { Biosurfactant } \\
\text { produced from } \\
\text { P. aeruginosa } \\
\text { PS16 }\end{array}$ & $\begin{array}{c}\text { Biosurfactant } \\
\text { produced from } \\
\text { P. aeruginosa } \\
\text { PP10 }\end{array}$ & $\begin{array}{c}\text { Without } \\
\text { biosurfactant }\end{array}$ \\
\hline $\begin{array}{c}\text { Mice with non- } \\
\text { contaminated } \\
\text { wounds by bacterial } \\
\text { suspension }\end{array}$ & 3 & 5 & 5 & 7 \\
\hline $\begin{array}{c}\text { Mice with } \\
\text { contaminated } \\
\text { wounds by bacterial } \\
\text { suspension }\end{array}$ & 3 & 10 & 12 & 17 \\
\hline
\end{tabular}




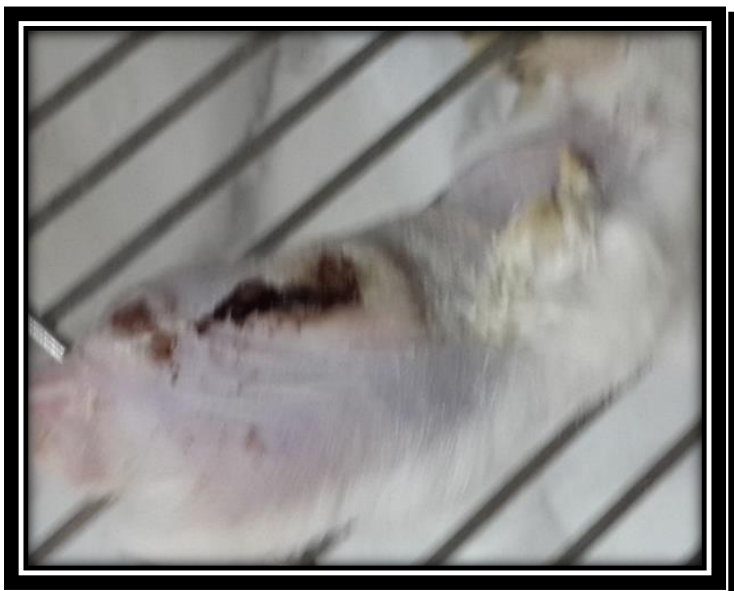

A) Sign of infected experimental animals by $P$. aeruginosa bacteria.

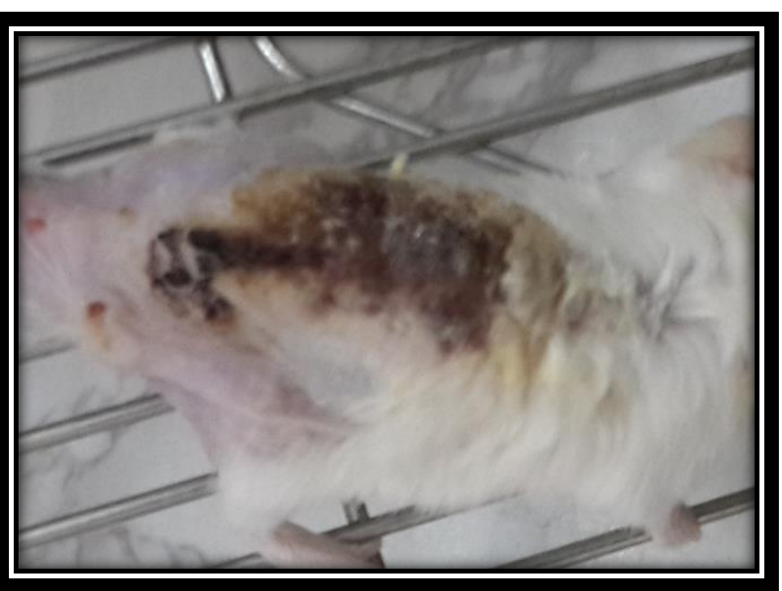

B) Progression of infection in control mice group after 10 days without treatment.

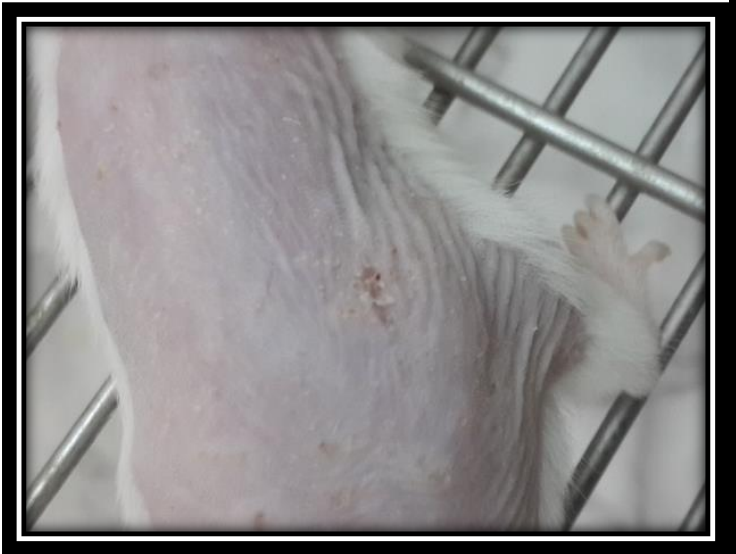

C) Complete recovery for infected animals after 10 days when treated with biosurfactant produced from $P$. aeruginosa PS16 at concentration $30 \mathrm{mg} / \mathrm{ml}$.

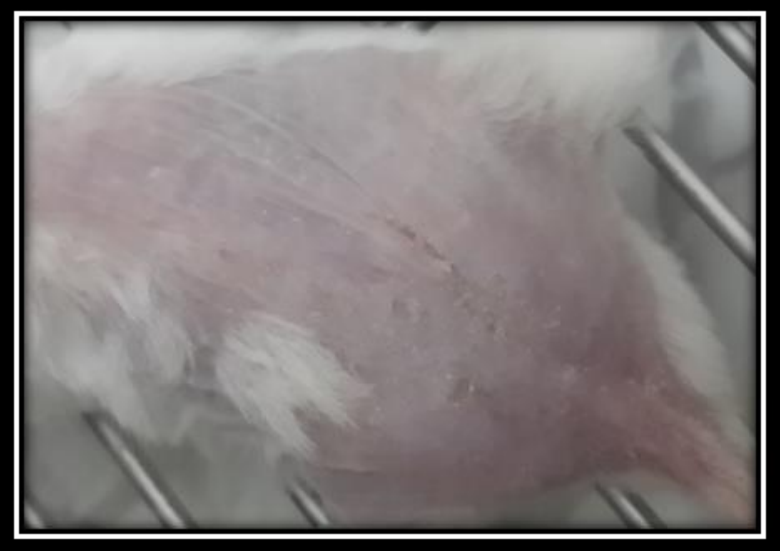

D) Complete recovery for infected animals after 12 days when treated with biosurfactant produced from $P$. aeruginosa PP10 at concentration $30 \mathrm{mg} / \mathrm{ml}$.

\section{Figure (6) mice infected by $P$. aeruginosa bacteria and treated with biosurfactant produced by $P$. aeruginosa PS16 and $P$. aeruginosa PP10 isolates.}

The results have emerged within vivo, consistent with what has previously been obtained in vitro in terms of the inhibitory effect of the produced biosurfactant against a number of pathogenic bacterial isolates. Although there are no studies that study the inhibitory effects the biosurfactants (rhamnolipids) against pathogenic bacteria in vivo, but there is a study of the effect of biosurfactants (rhamnolipids) on wound healing and their role in not forming a scar when healing and its efficacy in reducing the duration of healing. It was mentioned that rhamnolipid speed up the wound healing process and does not leave a scar [29] which is consistent with the results Current study as illustrated in (fig. 5) and (Fig.6), as in table (4) and table (5). 


\section{$\underline{\text { References }}$}

1. Karanth, N. G.; Deo, P.G. and Veenandig, N.K. 1990. Microbial production of biosurfactant and their importance. Pesticide residue Abatment Lab, food protectants and infestation control department.

2. Gautam, K.K. and Tyagi, U.K. 2006. Microbial surfactants. A review. J. Oleo Sci., 55(4), pp.155-166.

3. Banat, I.M.; Franzetti, A.; Gandolfi, I.;Bestetti, G.; Martinotti, M.G.;Fracchia, L.;Thomas, S. and Marchant R., 2010. Microbial biosurfactants production, applications and future potential. Appl Microbiol Biotechnol. 87, pp.427-444.

4. Van Hamme, J.D.; Singh, A. and Ward, O.P. 2006. Physiological aspects: Part1 in a series of papers devoted to surfactants in microbiology and biotechnology. Review Article Biotechnology Adv., 24, pp.604-620.

5. Banat, I.M.; Makkar, R.S. and Cameotra, S.S. 2000. Potential commercial applications of microbial surfactants. Applied Microbiology and Biotechnology. 53, pp.495-508.

6. Benincasa, M.; Contiero, J.; Manresa, M.A.; and Moreaes I.O. 2002. Rhamnolipid production by Pseudomonas aeruginosa LBI growing on soapstock as the sole carbon source. J Food Eng. 54, pp.283-288.

7. Nitschke, M. and Coasta S.G. 2007. Biosurfactants in food industry. Trends Food Sci. Technol. 18, pp.252-259.

8. Muthusamy, K.; Gopalakrishnan, S.;Ravi, T.K. and Sivachidambaram P. 2008 . Biosurfactants: Properties, commercial production and application. Current science. 94(6), pp.736-747.

9. Marchant, R. and Banat, I. M. 2012. Microbial biosurfactants: challenges and opportunities for future exploitation. Trends in Biotechnology. 30(11), pp.558-565.

10. Cameotra, S.S.and Makkar R.S. 2004. Recent applications of biosurfactants as biological and immunological molecules. Current Opinion in Microbiology. 7, pp.262-266.

11. Buchanan, R.E.; Gibbons, N.E.; Cowan, S.T.; Holt, T.G.; Liston, J.; Murry, R.G.;Niven, C.F.; Ravin, A.W. and Stainer, R.Y. 1974. Bergey's manual of determinative bacteriology. Williams and Wilkins Co., Baltimore, p1246.
12. Haba, E.; Pinazo, A.; Jauregui, O.; Espuny, M.J.; Infante, M. R., and Manresa, A. 2003. Physicochemical characterization and antimicrobial properties of rhamnolipids produced by Pseudomonas aeruginosa 47T2 NCBIM 40 044. Biotechnology and Bioengineering 81, pp.316- 322.

13. Sha, R.; Jiang,L.; Meng, Q.; Zhang, G. and Song, Z. 2011. Producing cell-free culture broth of rhamnolipids as a cost-effective fungicide against plant pathogens. Journal of Basic Microbiology.51, pp.1-9.

14. Forbes, B.A.; Saham, D.F. and Weissfeld, A.S. 2002. Baily and Scott's: Diagnostic Microbiology (11th edition). Mosby, Inc. Baltimore, USA. pp.384-398.

15. Jawetz, M. A.; Brooks, G.F.; Butel, J.S. and Morse, S.A. 2010. Medical microbiology. $25^{\text {th }}$ ed. Lang medical, McGraw-Hill, USA.

16. Folch, J.; Lees, M. and Stanley, GHS. 1957. A simple method for the isolation and purification of total lipides from animal tissues. J Biol Chem. 226, pp.497-509.

17. Petrikov, K.; Delegan, Ya.; Surin, A.; Ponamoreva, O.; Puntus, I.; Filonov, A. and Boronin, A. 2013. Glycolipids of Pseudomonas and Rhodococcus oil-degrading bacteria used in bioremediation preparations: Formation and structure. Process Biochemistry 48, pp.931-935.

18. Abbasi,H.; Hamedi, M.M.; Lotfabad, T.B.; Zahiri, H.S.; Sharafi, H. ; Masoomi, F.; Moosavi-Movahedi, A.A.; Ortiz, A.; Amanlou, M. and Noghabi, K.A. 2012 Biosurfactantproducing bacterium, Pseudomonas aeruginosa MA01 isolated from spoiled apples: physicochemical and structural characteristics of isolated biosurfactant. J. Biosci. Bioeng. 113, pp.211219.

19. Tayebe, B.L.; Fereshteh S. and Fahimeh S. 2013. Assessment of Antibacterial Capability of Rhamnolipids Produced by Two Indigenous Pseudomonas aeruginosa Strains. Jundishapur J Microbiol. 6, pp.29 - 35.

20 Woods GL, Washington JA. 1995. Manual of Clinical Microbiology. Washington. In: Murray PR, editor DC: ASM Press. pp. $1327-1341$.

21. Todar, K. 2004. Textbook of Bacteriology.University of Wisconsin Madison- department for microbiology. 
Toder's online available on: http://textbookofbacteriology.net/pseudomona s.html

22. Salleh, S. M.; Md Noh, N. A. and Yahya, A.R.M. 2011. Comparative study: Different recovery techniques of rhamnolipid bproduced by Pseudomonas aeruginosa USMAR-2. IPCBEE, vol.18

23. Gumma, Nahdem H. H. 2007. Treatment of petroleum pollutants by local isolates of Pseudomonas aeruginosa producing bioemulsifiers. $\mathrm{Ph}$. D. thesis. Collage of Science, Baghdad University. pp.30-31.

24. Hamburger, H. and Hostettmann, K. 1991. The link between phytochemistry and Medicine. Phytochemistry. 30, pp.3864-3874.

25. Al-Abodi, Nisreen J. M. 2001. Hemolysis and pathogenicity of Staphylococcus aureus isolated from animals sources. College of Education, University of Basrah. pp.20-21.

26. Nester , E. W. ; Anderson, D. G. ; Roberts , C. E. ; pearsall , N. N. \& Nester, M. T. 2001 Microbiology - Ahuman perspective $3^{\text {ed }}$ ed . Mc Graw - Hill Companies . U S A.

27. Al-Temimi, Ra'ad A. Hanon 2001. The effect of Fumaria parviflora and Prosopis farcta on some bacterial and fungal skin pathogens. Master Thesis. Collage of Science. ALMustansiriyah University. pp22-25.

28. Schaechter, M. ; Engleberg, N. C. ; Eisenstein , B. I. and Medoff, G. 1999. Mechanisms of Microbial Disease . $3^{\text {th }}$ ed ., Lippincott Williams \& Wilkins . A wolters kluwer company, USA.

29. Stipcevic, T.; Pijac ,A. and Pijac, G. 2006. Enhanced healing of full-thickness burn wounds using dirhamnolipid. Burns. 32, pp.24 
AL-Qadisiyah Journal of pure Science $\quad$ Vol.23 No. $1 \quad$ Year 2018 